International Journal of Agriculture, Environment and Bioresearch

Vol. 4, No. 04; 2019

ISSN: $2456-8643$

\title{
INFLUENCE OF THE SITE CONDITIONS ON THE LONG TERM EVOLUTION OF THE WEED FLORA AND OF ONION (ALLIUM CEPA L.)' PRODUCTION IN THE NORTH-EAST OF BENIN
}

\author{
Bello, S., Ahanchede, A., Amadji, G. L. and Maliki R. \\ ${ }^{1}$ Agricultural Research Center Center of the National Institute of Agricultural Research of Benin (INRAB / CRA- \\ Center), BP 112 Savè (Benin), Tel: 00229 94108119/66614547; \\ ${ }^{2}$ Faculty of Agricultural Sciences of the University of Abomey-Calavi (FSA / UAC), 01 BP 526 Cotonou, Benin, \\ http://doi.org/10.35410/IJAEB.2019.4432
}

\begin{abstract}
The present study has been conducted in order to put into relation the continuous farming duration, the soil texture and fertility level, the dominant species presence, the weed covering degree with the onion's bulb yield. it aims to determine also the term of putting onion's plots into fallow or abandonment in the North-East of Benin. Thirty-two onion plots have been considered in two villages named Kargui and Toumboutou, located respectively in the communes of Malanville and Karimama. Collected data have been submitted to one factor regression analysis with the general linear model and to the principal components analysis (PCA). Results have shown a quanlitative evolution of the flora characterized, depending on the soil texture, which is characterized by the erosion of the specific diversity. and its specialization by Cyperus rotundus and Portulaca quadrifida in a long term. This transformation of the flora in relation with the continuous crop duration is relative to the soil fertility and the onion' yield declining, which cause abandonment or fallow lying of plots for which these species are indicators. Concerned weeds are Boerhavia diffusa, Commelina benghalensis, Commelina diffusa, Cyperus tuberosus and especially Cyperus rotundus and Portulaca quadrifida which appear as dominant with the continuous cropping duration.
\end{abstract}

Keywords: Continuous cropping duration, fertility, manual weeding, onion, specy, yield.

\section{INTRODUCTION}

Control over grass is increasingly one of the main constraints to good crop production. According to Leroy (2011), weeding is not just the destruction of "weeds" or weeds on a plot, but an overall management of the cropping system. Based on this, the ITAB (2005) researchers recommended the reasoning of the choice of tools and the number of weed control interventions depending mainly on soil type, climatic conditions, nature and stage of development of the crop. and weeds present. This suggests that effective weed management requires control of the factors that promote competition between weeds and crop plants. Maintaining clean crops during the "critical period of competition" is essential for discounting maximum yields (Nieto et al., 1968). For a given crop, it is strongly influenced, according to Caussanel (1989), among others by factors such as the environment, the degree of infestation of the plot, the composition of the 
harmful flora and the density of the crop. Culture. According to Mesbah et al. (1994), plant species often grow in close association with weed competition for available nutrients, so that yield losses due to competition increase with increasing soil fertility levels because weeds are stimulated. This is how Bello et al. (2012b) found that an increase in mineral fertilizer dose promotes elongation and weed biomass production as well as increases height growth and onion yield.

The relative importance of the species on which the efforts of weeding must be carried out was discussed by Le Bourgeois (1993) in North-Cameroon. The results of this study have allowed this author to differentiate species with general or local distribution, which can be distinguished into two groups: that of species easy to control and that of species difficult to destroy. A phytosociological study of the onion-associated flora in cultivation conducted in northeastern Benin has made it possible to apprehend weed species with these characteristics (Bello et al., 2018, Bello et al., 2013).

However, the flora could also serve as an indicator of the level of fertility and / or the term of abandonment or set-aside of onion plots in northeastern Benin, a practice adopted by some onion producers when the grassing their plots becomes worrying. In Togo, cotton growers carried out one or two weeding at times of often too late intervention (Faure et al., 1988, Cousinie et al., 1989, Tonato et al., 1989, Tonato et al. . However, these authors found that the control of the main weeds composing the flora of this crop, including Digitaria horizontalis Willdenov, was hampered by an increase in their infestations, favored inter alia by plowing and cross-spraying by passage of discs. . The degree of weediness of the plots, the levels of infestation of the species present, the number and the periods of weeding that reflect the desire to completely destroy the weeds and the opportunity for systematic weed control influence the weediness of the weeds. as a result of their competition with a crop resulting in lower yield (Anonymous, 2002). This assertion leads us to appreciate in North-East Benin, the agro-ecological importance of the species of the flora of the plots of onion in terms of general or localized distribution. Indeed, this observation of Anonyme (2002) justifies the interrogations of Douti and Djagni (1995) who were preoccupied to know at first, (i) how to realize the maintenance of a culture during its cycle, in a second step, (ii) at what point of the crop cycle in relation to the critical competition period, weeding, and finally (iii) the effectiveness of weeding operations.

In the face of the desire to control the grassy plots of onion in North-East Benin, the present study was conducted to assess the influence of the duration of continuous cultivation, the texture and the level of soil fertility. and the state of grassing on the long-term qualitative evolution of the flora on the one hand and the yield of onion bulbs on the other hand.

\section{MATERIALS AND METHODS}

\section{Study area and plant material}

It consists of two villages, Kargui and Tomboutou located respectively in the communes of Karimama and Malanville to the Sudano-Sahelian climate with a variable annual rainfall of 800 to $900 \mathrm{~mm}$ (Figures 1a and 1b) according to the years (CARDER Borgou-Alibori, 1991, PADSE, 2001a, PADSE, 2001b, MAEP, 2002, CeCPA Malanville, 2006, CeCPA Karimama, 2006, 
CeCPA Karimama 2008). The soils had a sandy-clayey and sandy-silty texture (Bello 2004, Bello et al. In these localities, the cultivation of onion is practiced in lockers according to a mode of irrigation by gravity in counter-season. The plant material used was the purplish red onion of the local variety called "Aloubassa".

\section{Experimental apparatus}

The experimental set-up adopted was that of completely random blocks of 32 plots where each producer was a repetition.

\section{Collection of data}

Data collection was carried out from August to December by physical measurements on the experimental plots, individual and group semi-structured interviews and direct observations on the plots from the 32 producers who were actively involved.

The identification of weed species in onion traps was conducted in a participatory manner with producers during botanical exits during onion vegetation before weeding the plots. The botanical identification (genus, species and family) of the recorded species was made on the basis of Akobundu and Agyakwa descriptors (1989), then the scientific names were updated with information from the database of the website http: \\www. theplantist.org.

The variables measured and analyzed were related to site conditions, namely: (i) soil fertility level, (ii) soil texture, (iii) degree of grass cover, (iv) presence of species and ( v) the duration of continuous cultivation.

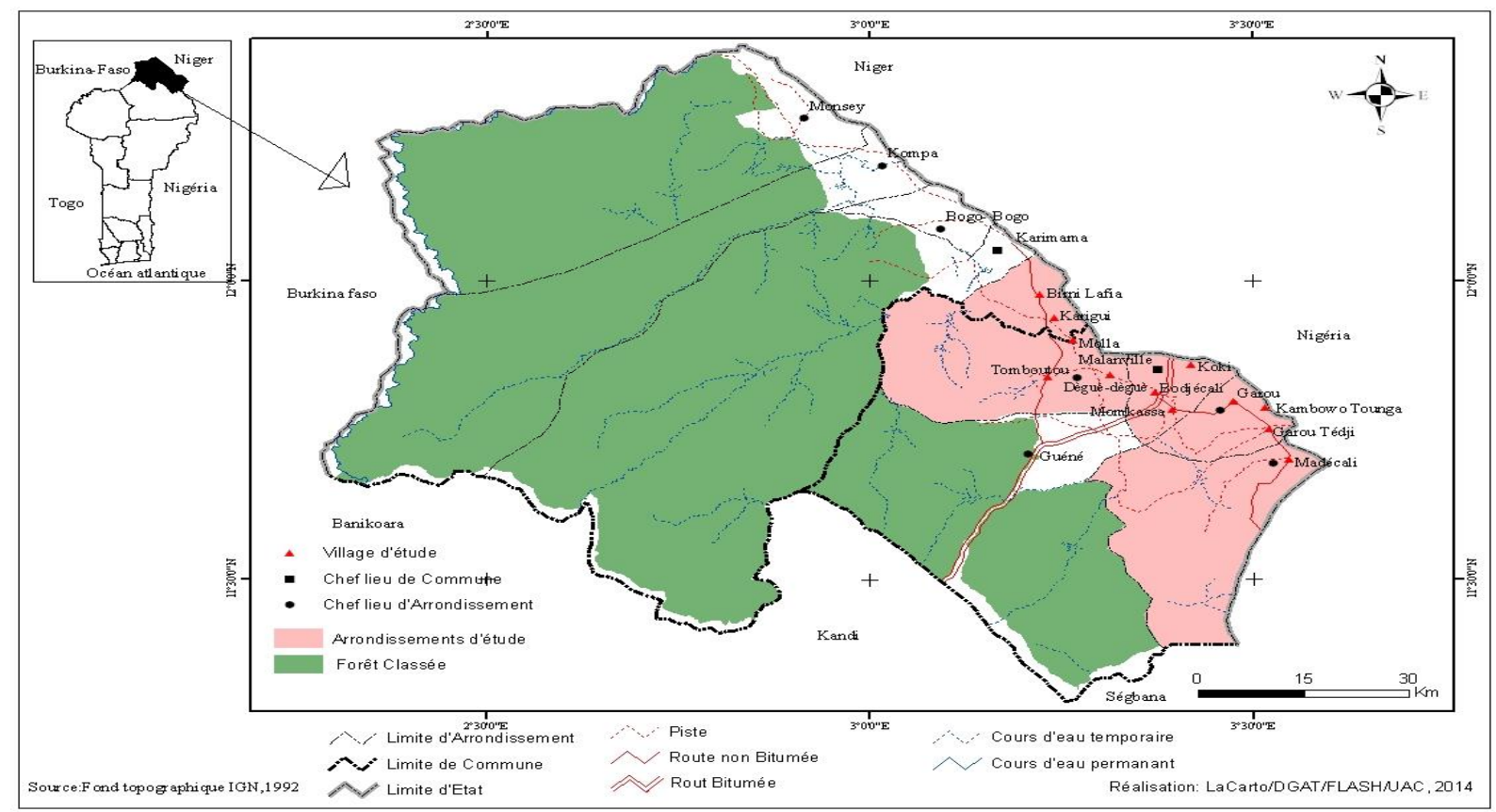


Figure 1: Map of Benin showing the study area represented by the communes of Malanville and Karimama (a) and the geographical location of the study villages (b)

Source: Directed by Bello (2013)

These measured variables as well as their modalities and associated levels, which also served as a qualitative and quantitative analysis grid for the data collected, were presented in Table 1.

The presence of the species was observed and the degree of weeding of the plots was measured before weeding carried out at the six periods indicated in Table 1. The method adopted to assess the degree of weeding is that of the count used by Chicouène (1999) which consists of counting weed species regardless of their stage of development. The species considered, when present, for abundance / dominance are Portulaca oleracea, Portulaca quadrifida and Cyperus rotundus determined by Bello et al. (2013); Bello et al. (2018); Bello et al. (2019a; 2019b).

Indicators of abandonment or fallowing of plots were defined as those species that appeared on the plots for a long period of continuous cultivation and whose control became difficult because of their persistence and resistance to development. the practice of manual weeding. In fact, this situation forced producers to abandon or put fallow onion parcels.

One species is described as a guide species with a general distribution when it is recorded on both types of soil identified on the basis of texture and the sum of these frequencies on these soils was less than or equal to $100 \%$.

In contrast, one species had a localized distribution when it was not identified on both soil types at a time and its frequency on plots of the given soil type where it was identified is less than $100 \%$.

Parcel weight data of onion bulbs expressed in $\mathrm{kg} / \mathrm{m}^{2}$ with the corresponding fertility level and soil texture were collected from the 32 producers during individual semi-structured interviews carried out and measured directly on the 32 plots of land. in ten plots each representing a trap of $3 \mathrm{~m}^{2}$, or $30 \mathrm{~m}^{2}$ per plot and per producer. Piecewise weights of harvested onion bulbs were used to calculate onion bulb yield ( $\mathrm{t} / \mathrm{ha}$ ), which was analyzed according to continuous culture time, soil texture, and soil fertility level (Table 1). .

Table 1: Nature and levels of explanatory variables related to site conditions

\begin{tabular}{|l|l|l|l|l|}
\hline \multicolumn{1}{|c|}{$\begin{array}{c}\text { Variables } \\
\text { analyzed }\end{array}$} & \multicolumn{2}{c|}{ Modalities and levels } & \multicolumn{1}{c|}{ observations } \\
\hline Soil texture & $\begin{array}{l}1: \text { Sablo-argileuse } \\
2: \text { Sablo-limoneuse }\end{array}$ & & $\begin{array}{l}\text { Results of the } \\
\text { article by Bello et } \\
\text { al. (2018) }\end{array}$ \\
\hline $\begin{array}{l}\text { Soil fertility level } \\
\text { (F) }\end{array}$ & $\begin{array}{l}\text { 1: Very fertile soil (MeF) } \\
\text { 2: Moderately fertile soil } \\
\text { (FMo) }\end{array}$ & & & \\
3: Poor soil (FF) & & & \\
\hline
\end{tabular}




\begin{tabular}{|c|c|c|c|c|}
\hline & $\begin{array}{l}\text { 1: Very high with } 71 \text { to } \\
100 \text { plants } / \mathrm{m}^{2} \\
\text { 2: Fairly high with } 51 \text { to } \\
70 \text { plants } / \mathrm{m}^{2} \\
\text { 3: Moderately high with } \\
21 \text { to } 50 \text { plants } / \mathrm{m}^{2} \\
\text { 4: Low with } 6 \text { to } 20 \\
\text { plants } / \mathrm{m}^{2} \\
\text { 5: None with } 0 \text { to } 5 \\
\text { plants } / \mathrm{m}^{2}\end{array}$ & & & \\
\hline $\begin{array}{l}\text { Degree of } \\
\text { grassing }\end{array}$ & & & 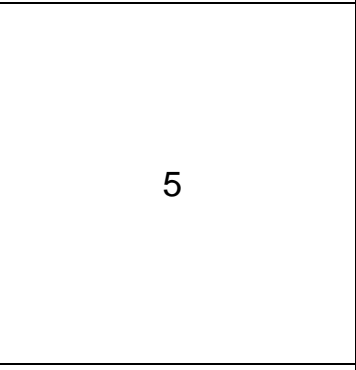 & $\begin{array}{l}\text { The counting } \\
\text { method was used } \\
\text { regardless of the } \\
\text { stage of } \\
\text { development of } \\
\text { the weeds } \\
\text { (Chicouène, 1999), } \\
\text { at the six weeding } \\
\text { periods indicated. }\end{array}$ \\
\hline $\begin{array}{l}\text { Presence of } \\
\text { species }\end{array}$ & Nature & Nombre & $\begin{array}{l}\text { Dominance }\left(^{*}\right) \\
\text { 1: Cyperus rotundus } \\
\text { 2: Portulaca } \\
\text { quadrifida } \\
\text { 3: Portulaca oleracea }\end{array}$ & $\begin{array}{l}\left({ }^{\star}\right)=\text { Specified } \\
\text { dominant species } \\
\text { Results from the } \\
\text { article by Bello et } \\
\text { al. }(2013) ; \text { Bello et } \\
\text { al. (2018); Bello et } \\
\text { al (2019a; 2019b) }\end{array}$ \\
\hline $\begin{array}{l}\text { Agro-ecological } \\
\text { importance of } \\
\text { species }\end{array}$ & $\begin{array}{l}\text { 1: General distribution } \\
\text { species in the study } \\
\text { area } \\
\text { 2: Species with } \\
\text { localized distribution } \\
\text { on onion plots } \\
\text { 3: Species indicative } \\
\text { of abandonment or } \\
\text { fallowing of plots }\end{array}$ & $\begin{array}{l}\text { Bello et al. } \\
\text { (2012a, } \\
\text { 2012b); Bello } \\
\text { et al. (2013); } \\
\text { Bello et al. } \\
\text { (2018) }\end{array}$ & & $\begin{array}{l}\text { 2: Species with } \\
\text { localized } \\
\text { distribution on } \\
\text { onion plots. They } \\
\text { were considered } \\
\text { according to the } \\
\text { duration } \\
\text { continuous } \\
\text { culture, } \\
\text { texture and the } \\
\text { level of fertility of } \\
\text { the soil: } \\
\text { 1: very fertile soil } \\
\text { (MeF) } \\
\text { 2: moderately } \\
\text { fertile soil (FMo) } \\
\text { 3: poor soil (FF) }\end{array}$ \\
\hline $\begin{array}{l}\text { Continuous } \\
\text { cultivation time } \\
\text { of plots } \\
\text { (cultivation } \\
\text { time) }\end{array}$ & Number of years & $\begin{array}{l}\text { Year 1: } 2000- \\
2001 \text { crop year }\end{array}$ & & \\
\hline
\end{tabular}

\section{DATA ANALYSIS}


The influence of these different variables on the long-term evolution of weed and yield was appreciated. The long-term evolution of grass cover in terms of its composition and the agroecological importance of the species has been analyzed. In this context, the species were characterized according to the duration of continuous culture, the texture and the level of soil fertility, depending on whether they are generally distributed guide species in the study area, localized distribution on plots of onion or indicator species of abandonment or fallowing of plots at the end of a period of continuous cultivation (Table 1).

The grouping of widespread distribution guide species was made on the basis of continuous culture time and soil texture.

Taking into account the ecological profile of species established by Bello et al. (2018), which highlighted the cosmopolitan character of certain species, the soil fertility level, the duration of continuous cultivation and the soil texture were considered as criteria for grouping locally distributed species on soils.

\section{Qualitative data analysis}

A content synthesis analysis was performed to categorize according to the duration of continuous culture and soil texture, associations of guide species that have a general distribution, and those that have a localized soil distribution of a fertility level. given. The indicator species of abandonment or fallowing of the plots as well as the average yield levels of onion bulbs recorded in relation to each level of fertility were related to the soil texture and the continuous culture time at which they match.

The yield was analyzed with a three-level analysis grid according to the soil texture as follows: (i) yield between 13 and $40 \mathrm{t} / \mathrm{ha}$ on very fertile soil (RdtMeF), (ii) between 9 at $20 \mathrm{t} / \mathrm{ha}$ on moderately fertile soil (RdtFMo) and (iii) between 6 and $11 \mathrm{t} /$ ha on poor soils named RdtFF (Table 1).

\section{Statistical analysis of the variables}

Minitab 14 software was used for the various statistical analyzes. A two-way analysis of variance was performed to assess the significance and comparison of onion bulb yield averages as a function of soil texture and soil fertility level with the Tukey test at the 5\% threshold. .

Similarly, a regression analysis was performed to determine yield trends, on the one hand, in relation to crop time, and on the other hand, soil texture and soil fertility. .

A Principal Component Analysis (PCA) based on the correlation matrix was performed to relate the crop time, soil fertility and soil texture variables to onion bulb yield.

\section{RESULTS}

The results obtained focused on the influence of the duration of continuous cultivation, the texture and the level of soil fertility on the composition and importance of the species of flora. On the other hand, they focused on the influence of site conditions on the yield of onion bulbs. 
Influence of continuous cultivation time, texture and soil fertility level on the composition and importance of flora species

The composition and importance of the flora in terms of species with widespread or localized distribution and species indicative of abandonment or fallowing of the plots as a function of the duration of continuous culture, texture and Soil fertility levels are presented in Tables 2 and 3.

These results are presented in two parts. The first was related to the analysis of the composition and representation of the species of flora according to the texture and level of soil fertility and the second focused on the influence of the duration of continuous culture, the texture and soil fertility on abandonment or fallowing of plots.

Composition and representation of flora species according to texture and soil fertility level

The composition and representation of species according to texture and fertility level are presented in Tables 2 and 3.

These tables indicated that 17 species are listed within the flora. These are Aneilema aequinoctial, Boerhavia diffusa, Brachiaria lata, Cassia tora, Commelina benghalensis, Commelina diffusa, Cyperus rotundus, Cyperus tuberosus, Dactyloctenium aegyptium, Digitaria nuda, Paspalum conjugatum, Pennisetum pedicellatum, Panicum subalbidum, Portulaca oleracea, Portulaca quadrifida, Setaria pallide fusca and AIDS acuta (Tables 2 and 3). Among them, Portulaca quadrifida, Portulaca oleracea and Cyperus rotundus, which have proved to be the most difficult of control (Bello et al., 2018), are associated with other less important ones such as Commelina benghalensis, Commelina diffusa, AIDS acuta, Digitaria nuda, Boerhavia diffusa, Brachiaria lata, Setaria pallidus fusca and Paspalum conjugatum.

These species do not have the same importance as regards their representation within the herbaceous flora (Table 3). Thus, 13 species namely, Aneilema aequinoctial, Boerhavia diffusa, Brachiaria lata, Cassia tora, Commelina benghalensis, Commelina diffusa, Cyperus rotundus, Dactyloctenium aegyptium, Digitaria nuda, Paspalum conjugatum, Pennisetum pedicellatum, Portulaca quadrifida and Sida acuta have a generalized representativeness on sandy-loamy and sandy-clay soils.

Among them, the 10 species named Aneilema aequinoctial, Boerhavia diffusa, Commelina benghalensis, Commelina diffusa, Cyperus rotundus, Cyperus tuberosus, Panicum subalbidum, Portulaca quadrifida, Setaria pallidus fusca and Sida acuta are found on moderately fertile soils. From this group, eight (08) namely, Boerhavia diffusa, Commelina benghalensis, Commelina diffusa, Cyperus rotundus, Cyperus tuberosus, Panicum subalbidum, Portulaca oleracea and Sida acuta, are represented on fertile soils. Finally, seven species; Boerhavia diffusa, Cassia tora, Commelina diffusa, Cyperus rotundus, Panicum subalbidum, Portulaca quadrifida and Sida acuta were present on poor soils. 
Table 2: Evolution of the composition and importance of the flora and relative yield levels of onion bulbs obtained on the onion crop plots as a function of the duration of continuous cultivation, the texture and the level of soil fertility

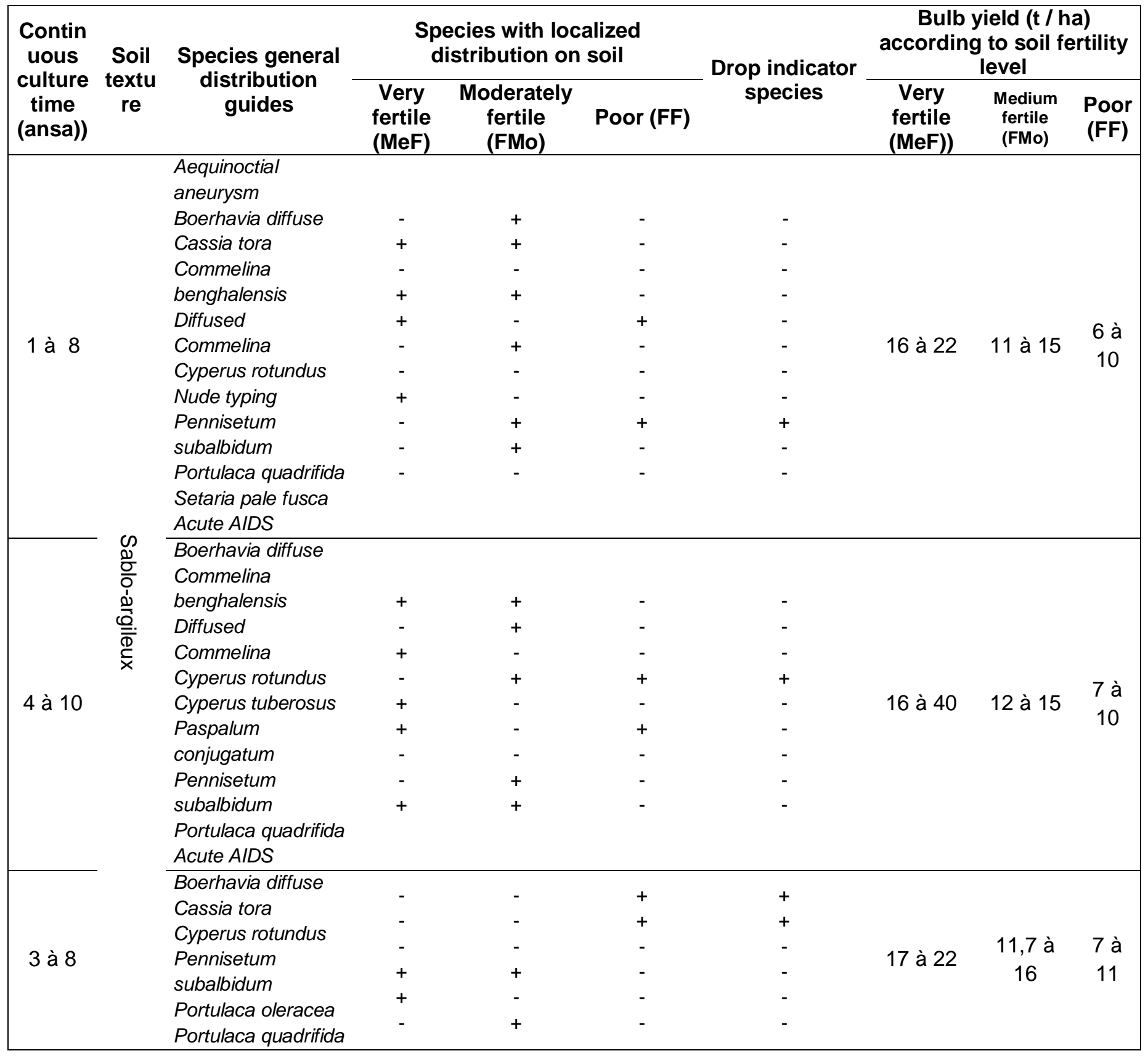


International Journal of Agriculture, Environment and Bioresearch

Vol. 4, No. 04; 2019

ISSN: $2456-8643$

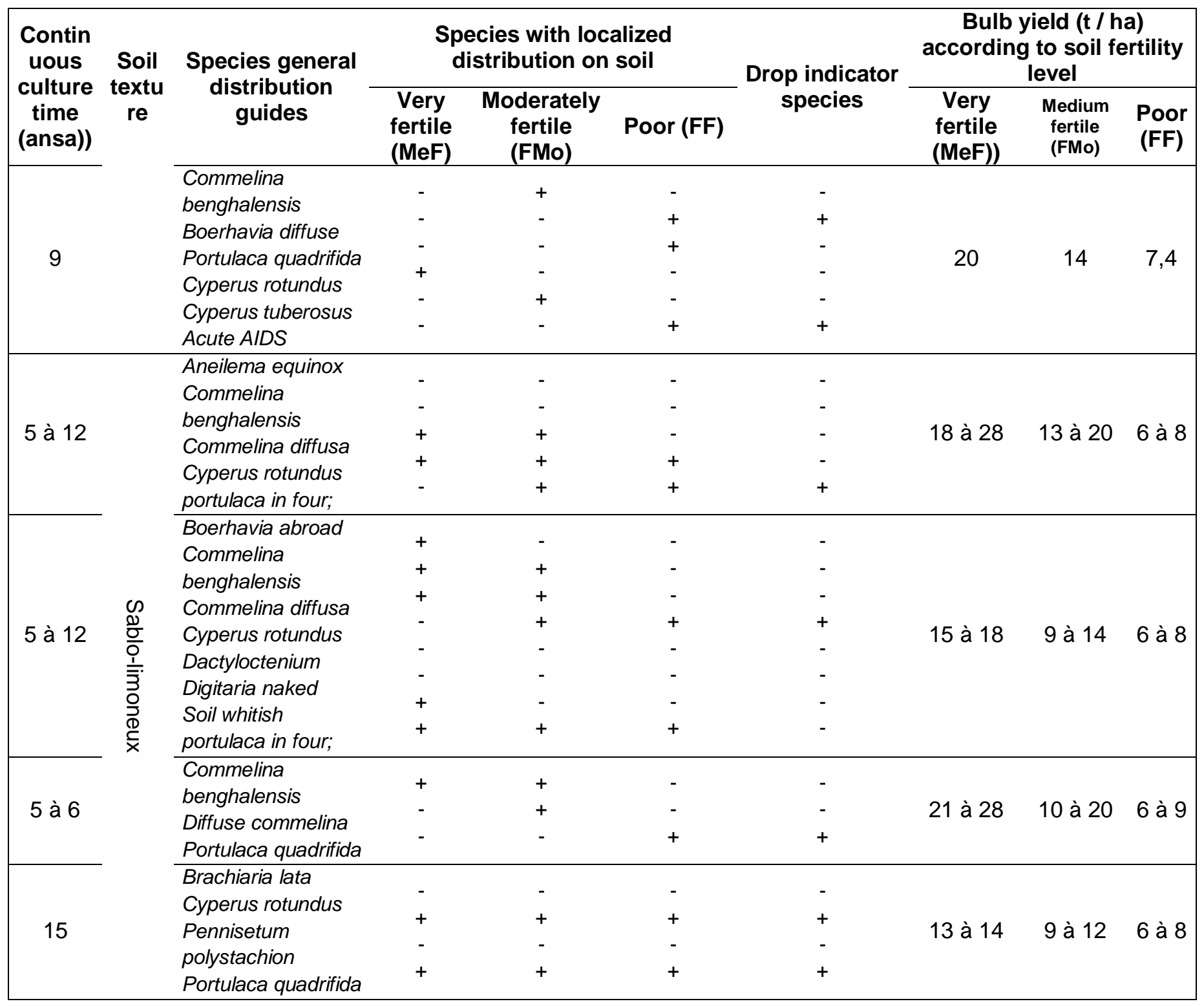


Table 3: Distribution of species by texture and soil fertility level

\begin{tabular}{|c|c|c|c|c|c|c|c|c|c|c|c|c|}
\hline \multirow{3}{*}{ Species } & \multirow{2}{*}{\multicolumn{3}{|c|}{$\begin{array}{l}\text { Species general } \\
\text { distribution guides }\end{array}$}} & \multicolumn{9}{|c|}{ Species with localized distribution on soil } \\
\hline & & & & \multicolumn{3}{|c|}{ Very fertile (MeF)) } & \multicolumn{3}{|c|}{$\begin{array}{l}\text { Moderately fertile } \\
\text { (FMo) }\end{array}$} & \multicolumn{3}{|c|}{ Poor (FF) } \\
\hline & SA & SL & C & SA & SL & $\mathbf{C}$ & SA & SL & C & SA & SL & $\mathbf{C}$ \\
\hline Aneilema aequinoctiale & + & + & + & - & - & - & - & - & - & - & - & - \\
\hline Boerhavia diffusa & + & + & + & + & + & + & + & - & - & + & - & - \\
\hline Brachiaria lata & - & + & - & - & - & - & - & - & - & - & - & - \\
\hline Cassia tora & + & - & - & - & - & - & - & - & - & + & - & - \\
\hline Commelina & + & + & + & + & + & + & + & + & + & - & - & - \\
\hline benghalensis & - & + & - & + & + & + & - & + & - & + & - & - \\
\hline Commelina diffusa & + & - & - & + & + & + & + & + & + & + & + & + \\
\hline Cyperus rotundus & - & + & - & + & - & - & + & - & - & - & - & - \\
\hline Cyperus tuberosus & - & + & - & - & - & - & - & - & - & - & - & - \\
\hline Dactyloctenium & + & + & + & - & - & - & - & - & - & - & - & - \\
\hline aegyptium & + & - & - & - & - & - & - & - & - & - & - & - \\
\hline Digitaria nuda & + & + & + & + & - & - & + & - & - & + & - & - \\
\hline Paspalum conjugatum & - & + & - & - & + & - & - & - & - & - & - & - \\
\hline Panicum subalbidum & - & - & - & + & - & - & - & - & - & - & - & - \\
\hline $\begin{array}{l}\text { Pennisetum } \\
\text { pedicellatum }\end{array}$ & + & + & + & - & + & - & + & + & + & + & + & + \\
\hline Portulaca oleracea & - & - & - & - & - & - & + & - & - & - & - & - \\
\hline Portulaca quadrifida & + & - & - & + & - & - & + & - & - & + & - & - \\
\hline Setaria pallide fusca & & & & & & & & & & & & \\
\hline Sida acuta & & & & & & & & & & & & \\
\hline
\end{tabular}

Legend: $\mathrm{SA}=$ sandy loam soil; $\mathrm{SL}=$ sandy loam; $\mathrm{C}=$ Common to both types of soil; $+=$ Presence; - = Absence

Unlike Portulaca quadriifida and Cyperus rotundus, which appear at the end of several cycles of short rotations, the last seven species, Boerhavia diffusa, Cassia tora, Commelina diffusa, Cyperus rotundus, Panicum subalbidum, Portulaca quadrifida, and Sida acuta were the most represented.

Influence of continuous cultivation time, texture and soil fertility on abandonment or fallowing of plots

The analysis of the information in Table 2 indicated that Portulaca quadrifida is a species that settles for a prolonged period starting from the first year with the clearing of plots on sandy-clay soil and from the fifth year on sandy-loamy soil. within the flora. Portulaca quadrifida is associated with eight (08) other species in sandy-clay soil within a flora that was more diverse than on sandy-loam soils where the number of species recorded is four (04). With an early onset during the first year of cultivation, it truly became on sandy-clay soil, a species indicative of 
abandonment or fallow plots from the eighth year. On sandy-loam soil, it acquired this importance from the twelfth year.

Cyperus rotundus appeared from the fourth year of cultivation on sandy-clay soil and sandyloam soil. Its flora was rich of five (05) species on sandy-clay soil against eight (08) in sandyloam soil. This species really indicated the abandonment or fallowing of the plots from the tenth year on sandy-clay soil and from the eighth year on sandy-silty soil.

Portulaca quadrifida and Cyperus rotundus were indicative of abandonment or fallowing of plots subjected to continuous cultivation from the eighth year on moderately fertile sandy-clay soil. They were also from grade 10 on moderately fertile and poor sandy-clay soils. They were the same indicators for this situation from the twelfth year and the fifteenth year on moderately fertile and poor sandy-loam soils.

Grass cover in Portulaca quadrifida resulted in earlier abandonment of plots, first to 8th year of continuous cultivation on sandy-clay soil and from 5th to 12th year on sandy-loam soil. In the presence of Cyperus rotundus, this period is 4 to 10 years on sandy-clay soil and 5 to 12 years on sandy-loam soil.

These results indicated that fallowing of sandy-clay soils is more delayed in the presence of Cyperus rotundus than of Portulaca quadrifida. A long period of continuous cultivation on sandyloam soil of about fifteen years is marked by the appearance of both species.

Influence of continuous cultivation time, texture and soil fertility level on onion bulb yield evolution

The data in Table 4 show that the yield of onion bulbs was highly variable depending on the duration of continuous cultivation, the texture and the level of soil fertility. In sandy-clay soil, yield levels ranged from $12 \mathrm{t} /$ ha to $39 \mathrm{t} / \mathrm{ha}$ on very fertile soil, from $10 \mathrm{t} / \mathrm{ha}$ to $27.5 \mathrm{t} /$ ha on medium-fertile soil and $6.5 \mathrm{t} /$ ha at $13 \mathrm{t} /$ ha on poor soil. The production of onion bulbs thus decreased with the decline in the level of soil fertility. On the other hand, in sandy-loam soil, it ranged respectively from $12 \mathrm{t} /$ ha to $21 \mathrm{t} / \mathrm{ha}$, from $10 \mathrm{t} /$ ha to $13.33 \mathrm{t} /$ ha and from $4.7 \mathrm{t} / \mathrm{ha}$ to $6 \mathrm{t} / \mathrm{ha}$. The estimated annual average yield for all fertility levels is $14.13 \pm 0.44 \mathrm{t} / \mathrm{ha}$ on sandyclay soil compared to $11.29 \pm 0.52 \mathrm{t} /$ ha on sandy-loam soil. The annual average for both soil types is $18.53 \pm 1.65 \mathrm{t} /$ ha in fertile soil, $13.02 \pm 1.15 \mathrm{t} /$ ha in moderately fertile soil and $7.01 \pm$ $0.61 \mathrm{t} /$ ha in poor soil (Table 4).

The texture and soil ferocity variables each influenced the yield very highly $(p=0.000)$. However, they do not interact $(\mathrm{p}=0.843)$ on onion production (Table 4$)$.

The results of the principal component analysis performed on the variables continuous culture time, texture and soil fertility level gave the results presented in Table 5 and Figure 1. These results showed that the first two axes explain $77 \%$ of the total variation. Therefore, these two axes are retained to describe the relationship between these variables and the yield.

The analysis in Table 5 indicated that the first axis shows a positive relationship with each of the variables continuous crop time and soil texture. Axis 2 showed a positive relationship with the 
continuous culture duration variable and a negative link with the variable soil fertility level. These correlations are illustrated in Figure 1.

Table 4: Results of variance analysis of onion bulb yield ( $t / \mathrm{ha}$ ) evaluated on onion plots of different textures and fertility levels

\begin{tabular}{|c|c|c|c|c|}
\hline \multirow{2}{*}{\begin{tabular}{|l|}
$\begin{array}{c}\text { Continuous culture } \\
\text { time (years) }\end{array}$ \\
1 à 10 \\
\end{tabular}} & \multirow{2}{*}{$\begin{array}{l}\text { Soil texture } \\
\text { Sandy clay }\end{array}$} & \multicolumn{3}{|c|}{ Levels of yield ( $t$ / ha) in soil onion bulbs } \\
\hline & & $\begin{array}{c}\text { Very fertile } \\
\text { (MeF) }\end{array}$ & $\begin{array}{c}\text { Moderately fertile } \\
\text { (FMo)) }\end{array}$ & $\begin{array}{c}\text { Moderately } \\
\text { fertile (FMo)) }\end{array}$ \\
\hline Average & & $19,97 \pm 2,57$ & $14,17 \pm 1,79$ & $8,21 \pm 0,75$ \\
\hline Great average & & \multicolumn{3}{|c|}{$14,13 \pm 0,44$} \\
\hline 5 à 15 & Sandy loam & $\begin{array}{l}\text { Very fertile } \\
\text { (MeF) }\end{array}$ & $\begin{array}{c}\text { Moderately } \\
\text { fertile (FMo)) }\end{array}$ & Pauvre (FF) \\
\hline Average & & $16,37 \pm 1,32$ & $11,29 \pm 0,82$ & $5,22 \pm 0,42$ \\
\hline Great average & & \multicolumn{3}{|c|}{$11,29 \pm 0,52$} \\
\hline Overall average & & $18,53 \pm 1,65$ & $13,02 \pm 1,15$ & $7,01 \pm 0,61$ \\
\hline $\begin{array}{c}\text { Sources of } \\
\text { variation }\end{array}$ & Soil texture & Soil texture... & $\begin{array}{l}\text { Soil texture * } \\
\text { Fertility level }\end{array}$ & \\
\hline Probabilité & 0,000 & 0,000 & 0,843 & \\
\hline $\mathrm{F}$ & 17,56 & 105,44 & 0,17 & \\
\hline
\end{tabular}

Table 5: Results of the Principal Component Analysis (PCA) of the relationship of the variables continuous culture time, texture and soil fertility level with onion bulb yield ( $t$ / ha)

\begin{tabular}{|l|c|c|c|}
\hline \multicolumn{4}{|c|}{$\begin{array}{c}\text { Eigen values of the correlation matrix between variables and } \\
\text { principal components }\end{array}$} \\
\hline Eigenvalue & 1,3289 & 0,9804 & 0,6908 \\
\hline Proportion & 0,443 & 0,327 & 0,230 \\
\hline Cumulatif & 0,443 & 0,770 & 1,000 \\
\hline Variables & PC 1 & PC 2 & PC 3 \\
\hline Continuous culture time & 0,576 & 0,581 & $-0,575$ \\
\hline Soil texture & 0,696 & 0,021 & 0,718 \\
\hline Soil fertility level & 0,429 & $-0,814$ & $-0,392$ \\
\hline
\end{tabular}




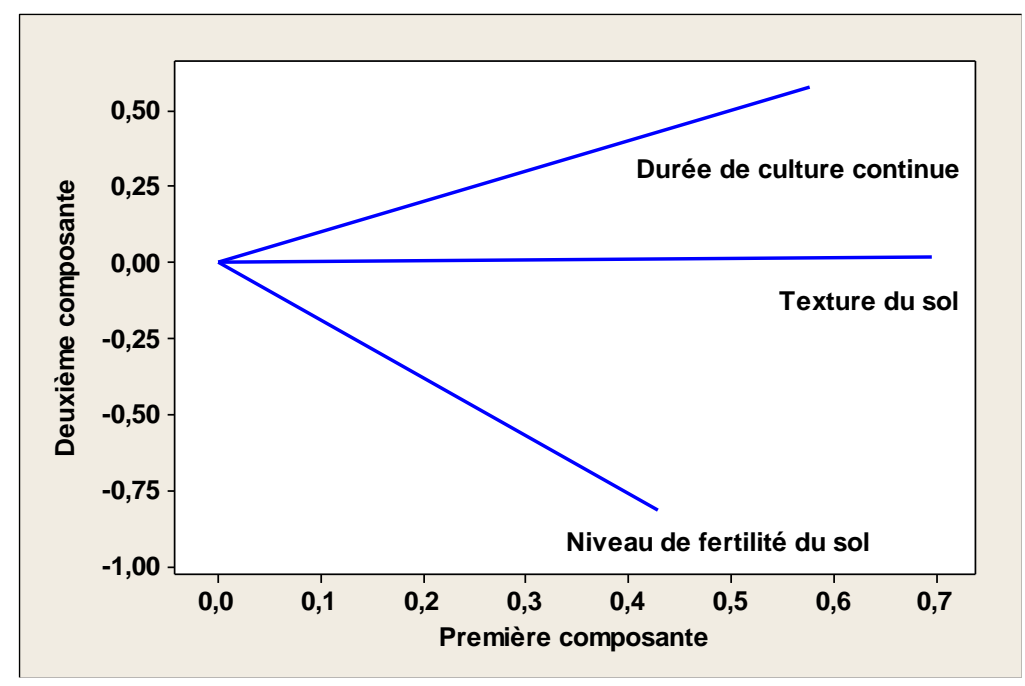

Figure 1: Correlation diagram between the variables continuous crop time, texture and soil fertility level on the first two axes

Figure 2 shows the projection of onion bulb yield levels in the system of axes 1 and 2.

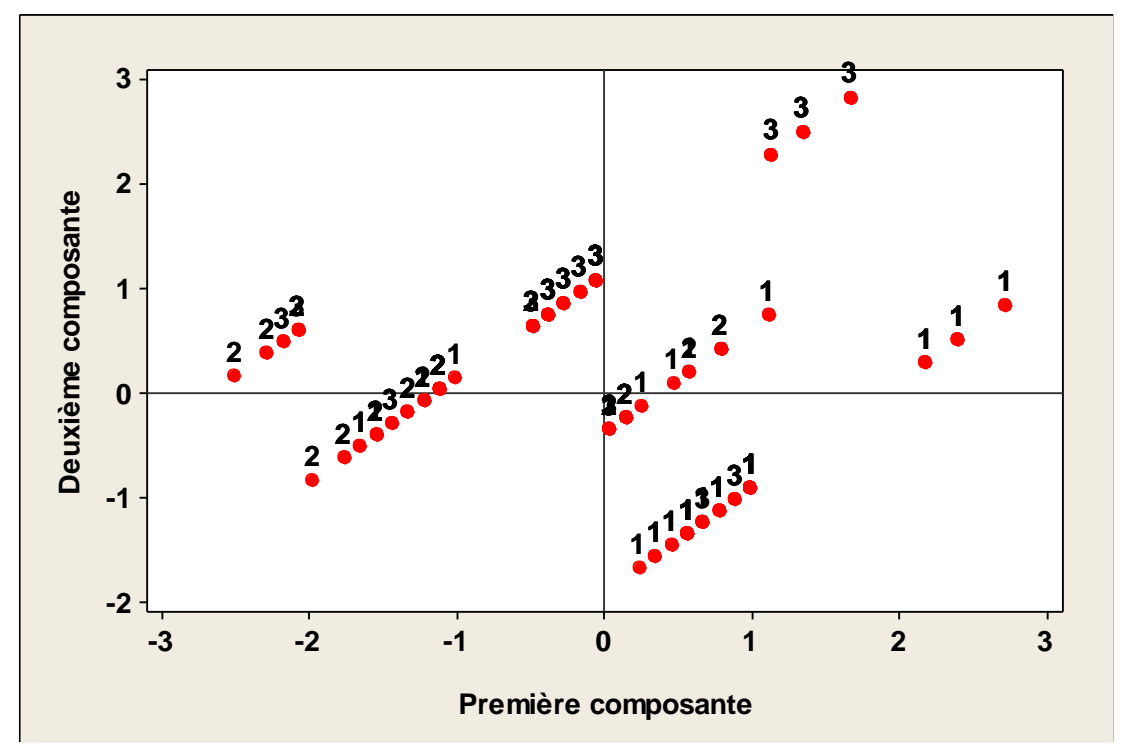

Figure 2: Projection of Onion Bulb ( $\mathrm{t}$ / ha) yield levels on Axis Systems 1 and 2 Legend:

$1=$ Low yield level equivalent to $7.01 \pm 0.61 \mathrm{t} / \mathrm{ha}$ 
$2=$ Average yield level equivalent to $13.02 \pm 1.15 \mathrm{t} / \mathrm{ha}$

$3=$ High yield level equivalent to $18.53 \pm 1.65 \mathrm{t} /$ ha

High yield levels could be attributed to short durations of continuous culture (Figures 1 and 2). In contrast, average and low yield levels are attributed to soil texture. However, high and low yield levels are also attributed to the level of soil fertility.

\section{Influence of fertility level and soil texture on the evolution of onion bulb yield}

The results in Table 6 show that soil texture variables and soil fertility levels accounted for at least $60 \%$ onion yield, with $63.71 \%$ and $62.36 \%$ correlation coefficients, respectively. . The regression equation (Figure 3 ) for a sandy-clay texture soil is written as: Onion yield $(\mathrm{t} / \mathrm{ha})=$ $12.71+1.4214 * \mathrm{~T}$ with $\mathrm{T}$ the fertility level for which $\mathrm{T} 1=$ high $=1, \mathrm{~T} 2=$ average $=2, \mathrm{~T} 3=$ weak $($ poor soil $)=3$

Table 6: Results of the regression analysis of onion bulb yield ( $t$ / ha) as a function of soil texture and fertility level

\begin{tabular}{|lcccc|}
\hline Termes & Coefficient & SE Coefficient & T & P \\
\hline Constant & 12,71 & 0,3392 & $\begin{array}{c}37,47 \\
\mathrm{R}^{2}(\mathrm{adj})=\end{array}$ & 0,000 \\
Correlation & $\mathrm{S}=3,96296$ & $\mathrm{R}^{2}=63,71 \%$ & 4,19 & 0,000 \\
Sandy clay soil & 1,4214 & 0,3392 & & \\
Fertility level & & & 12,18 & 0,000 \\
High & 5,8712 & 0,4821 & 0,70 & 0,487 \\
Way & 0,3338 & 0,4785 & & \\
Soil type * Fertility level & & & 0,22 & 0,82 \\
High for sandy clay soil & 0,1178 & 0,48 & $-0,58$ & 0,564 \\
Medium for sandy clay soil & $-0,2770$ & 0,4785 & & \\
\hline
\end{tabular}

The sandy-clay texture and the high fertility level were very highly significant for the yield. However, for sandy-clay soils, the effect of average fertility level on yield was not significant ( $>$ 0.05). Similarly, the high and medium fertility levels had no interaction effect with soil texture on yield for this type of soil. 


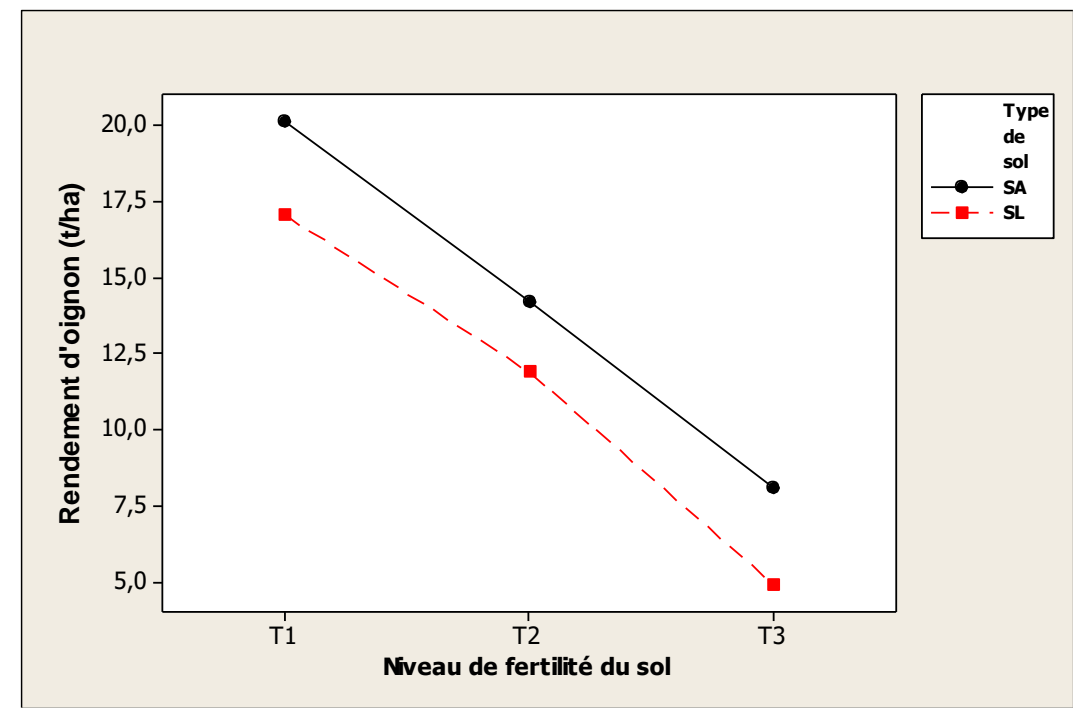

Figure 3: Yield regression curves ( $\mathrm{t} / \mathrm{ha}$ ) as a function of the soil fertility level for the two types of soils of sandy-clayey (SA) and sandy-silty (SL) texture

Legend: $\mathrm{T} 1=$ High fertility level $=1, \mathrm{~T} 2=$ Mean fertility level $=2, \mathrm{~T} 3=$ Low fertility level $($ poor soil $)=3$

Influence of the duration of continuous culture on the evolution of the yield of onion bulbs

A regression analysis performed on the yield variables for the period from 2000 to 2009 and duration of continuous culture gave the results presented in Table 7 . The average annual yields are very very significantly different from one year to another $(\mathrm{p}<0.001)$ and the onion bulb yield is strongly correlated, but negatively, with the continuous culture time $(\mathrm{p}<0.001$ with a coefficient of determination $\mathrm{R}^{2}=91.9 \%$ and adjusted $\mathrm{R}^{2}=90.7 \%$ ). Yield levels decreased with continuous crop time at a linear rate. The equation of this determined regression is written $\mathrm{Y}=$ $33.6-1.6 *$ Continuous culture time (Figure 4).

In fact, during the first years of continuous cultivation, the yield is at a high level, of $31 \mathrm{t} / \mathrm{ha}$ depending on the cultivation techniques applied related to the fertilizer dose, the onion transplanting density, the mode, the number or period and effectiveness of manual weed control and initial soil fertility. With the extension of the continuous cropping period, the yield decreased steadily to reach fairly low levels of $17 \mathrm{t} / \mathrm{ha}$, or about $50 \%$ after nine (9) successive cropping seasons.

Cultivation continued by producers on sandy-loam soils ranged from eighteen (18) years to at most 20 years, while on sandy-clay soils, they lasted at most 32 years.

Table 7: Results of the regression analysis of the evolution of onion bulb yield ( $t / \mathrm{ha}$ ) as a function of the continuous cultivation time (in number of years) of the plots 
International Journal of Agriculture, Environment and Bioresearch

Vol. 4, No. 04; 2019

ISSN: $2456-8643$

\begin{tabular}{|lccc|}
\hline Source of variation & Constant & Crop time & Regression \\
\hline ddl & - & 8 & 1 \\
Probability & $0,000^{* * *}$ & $0,000^{* * *}$ & $0,000^{* *}$ \\
T (F) & 28,42 & $-8,90$ & $12,48(\mathrm{~F})$ \\
Coefficient & 33,556 & $-1,8667$ & - \\
\hline \multicolumn{2}{l}{$* * *:(p<0.001)=$ very very highly significant } &
\end{tabular}

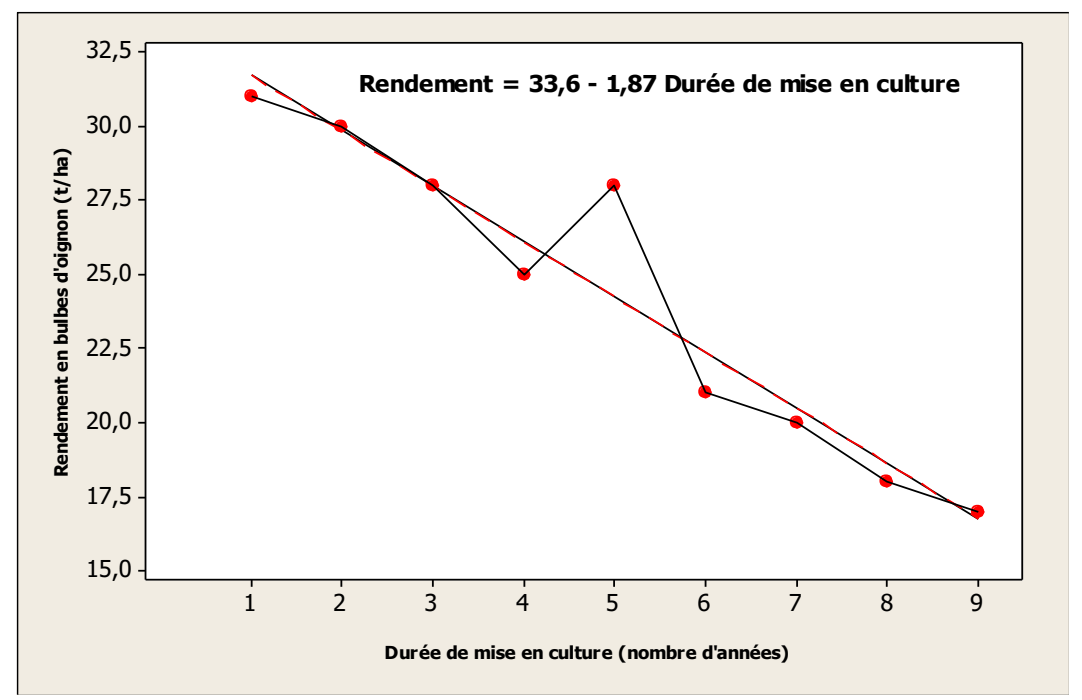

Figure 4: Evolution of onion yield ( $\mathrm{t} / \mathrm{ha}$ ) as a function of the continuous cultivation time (number of years) of plots from 2000 to 2009

\section{Influence of site conditions on onion bulb yield}

Principal components analysis performed on variables Continuous Crop Time, Soil Texture, Generalized Distribution Species, High Fertile Soil (MeF) Localized Distribution Species, Medium Fertility Soil-Affected Species (FMO Esp) ), Localized Low Fertility Soil (FF) Species, Soil Fertility Level, and Ab Ind Point Species (Ab Ind) gave the results presented in Table 8 and Figures 5 and 6.

These results show that the first two axes explain 54\% of the total variation of the variables. Therefore, these two axes have been retained to describe the relationship between these variables and performance.

The information retained by these axes was examined from their correlations with the initial variables (Table 8). Analysis of this table indicates that the first axis shows a positive relationship with the soil texture variable. Axis 2 shows a negative link with the variable Continuous culture duration and a positive link with the variable Species with localized 
distribution on soil with medium fertility (Esp FMo). These correlations are illustrated in Figure 5 .

Table 8: Results of the Principal Component Analysis (PCA) of the linking of site conditions with onion bulb yield (t / ha)

\begin{tabular}{|l|c|c|c|}
\hline Statistical parameters & PC1 & PC2 & Cumul \\
\hline Eigenvalue & $\mathbf{1 , 7 6 8 0}$ & $\mathbf{1 , 4 3 4 4}$ & $\mathbf{1 , 1 3 2 5}$ \\
\hline Proportion & $\mathbf{0 , 2 2 1}$ & $\mathbf{0 , 1 7 9}$ & $\mathbf{0 , 1 4 2}$ \\
\hline Cumulatif & 0,221 & 0,400 & 0,542 \\
\hline Variables & & & \\
\hline Continuous culture time & $-0,229$ & $-0,533$ & \\
\hline Soil texture & 0,601 & $-0,006$ & \\
\hline Guide species with widespread distribution & 0,222 & 0,367 & \\
\hline $\begin{array}{l}\text { Species with localized distribution on soil with } \\
\text { high fertility (MeF) }\end{array}$ & 0,396 & $-0,370$ & \\
\hline $\begin{array}{l}\text { Species with localized distribution on medium } \\
\text { fertility soil (FMo Esp) }\end{array}$ & 0,262 & 0,545 & \\
\hline $\begin{array}{l}\text { Species with localized distribution on low } \\
\text { fertility soil (Esp FF) }\end{array}$ & 0,433 & $-0,369$ & \\
\hline Soil fertility level & 0,024 & $-0,003$ & \\
\hline $\begin{array}{l}\text { Species Indicators of Abandonment (Esp Ind } \\
\text { Ab) }\end{array}$ & 0,352 & $-0,103$ & \\
\hline
\end{tabular}

Figure 6 shows the projection of onion bulb yield levels in the system of axes 1 and 2. It shows that onion bulb yield levels are distributed in all four regions of the plane of the two axes.

This observation shows that apart from the duration of continuous culture, soil texture and the presence of localized species on soil with medium fertility (Esp FMo), none of the variables studied has a significant influence. on the level of yield in onion bulbs.

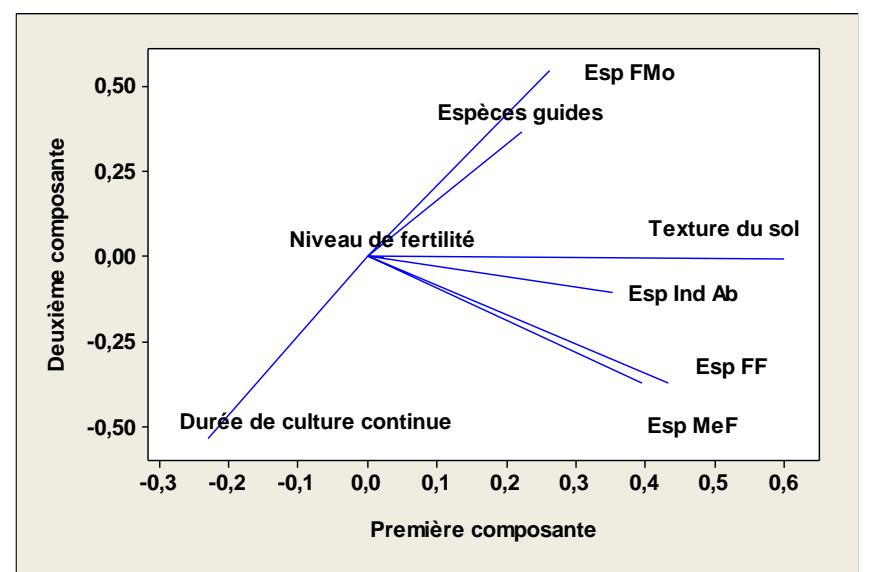


Figure 5: Correlation circle between site condition variables and the first two axes

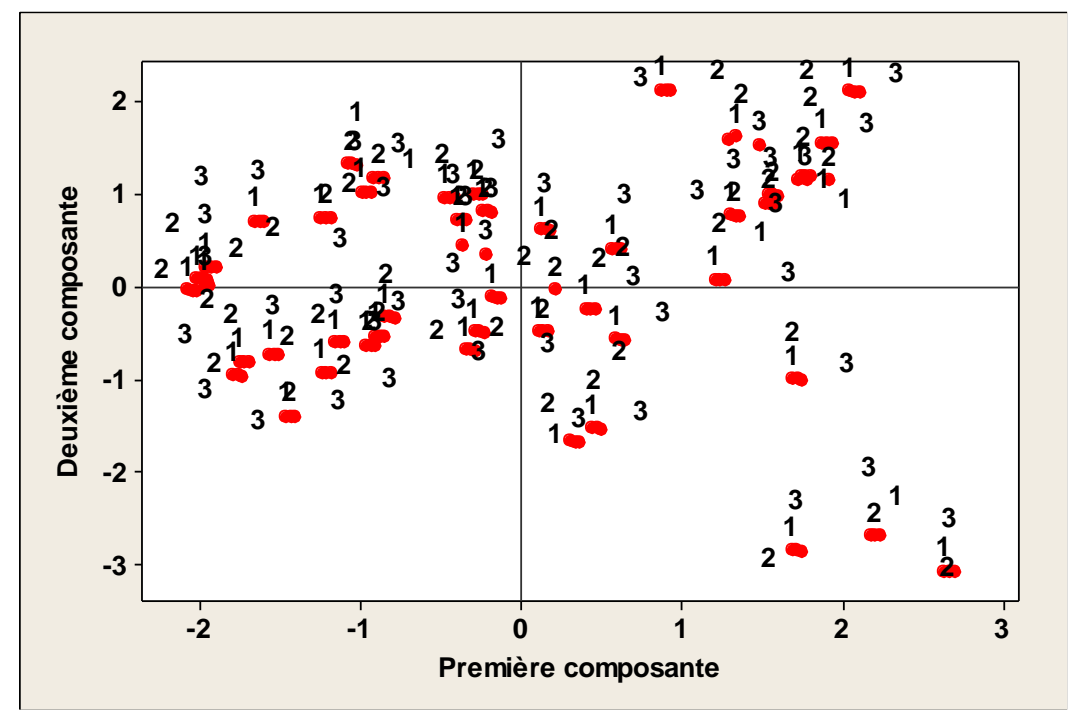

Figure 6: Projection of yield variable in onion bulbs ( $\mathrm{t} / \mathrm{ha}$ ) on Axis Systems 1 and 2

Legend:

$1=$ Low yield level equivalent to $7.01 \pm 0.61 \mathrm{t} / \mathrm{ha}$

$2=$ Average yield level equivalent to $13.02 \pm 1.15 \mathrm{t} / \mathrm{ha}$

3 = High yield level equivalent to $18.53 \pm 1.65 \mathrm{t} / \mathrm{ha}$

\section{DISCUSSION}

Influence of continuous cultivation, texture and soil fertility on the composition, importance and specialization of flora

The species recorded and their associations vary according to the duration of continuous cultivation, the texture and the level of soil fertility. With continuous cultivation, the number of species present especially on poor soil is lower than on very fertile and moderately fertile soils. The results presented in Tables 2 and 3 show that the flora represented by the 17 identified species formed different species associations according to the soil texture, soil fertility level and the importance of "generalized representation guide" or of "localized representation on a soil of a given level of fertility" that can be attributed to species. A longer period of continuous cultivation leads to a trend towards the specialization of the flora of Portulaca quadrifida and Cyperus rotundus, regardless of the soil texture and the level of soil fertility. The presence of these major species in onion culture has been perceived as a characteristic of the flora of grassy onion plots in relation to environmental conditions and agro-system characteristics (Anonymous, 2004). 
The onion cropping systems practiced are pure onion cultivation with previous cultivations, green pepper and tomato in $26.37 \%$ of cases where cereals corn and rice in $23.08 \%$ of cases and sorghum in 13\%., 19\% of cases (Bello, 2012). The rotation cycle is short-lived, from three to five years. Millet, rice, chilli and squash (Benincasa hispida) are more involved in monoculture than in crop rotation, much less on plots usually used for onions (Bello, 2012). These cropping systems are therefore characterized by a low diversification of crops for rotation, which leads, according to Bonté (2010), to a specialization of the flora in Portulaca quadrifida and Cyperus rotundus as observed. Bonté (2010) justified this finding with the argument that the density of weeds before planting cereals increased from 142 to 35 plants $/ \mathrm{m}^{2}$ as the number of crops in the rotation increased. This author therefore concluded that "rotation plays a key role in the control of weed control by the succession of different crops, the reduction of the seed stock, the limitation of proliferation and the disruption of the weed cycle".

In the study area, the operating life of onion plots ranged from eight to 32 years on the basis of several short rotation cycles, and thus a low diversity of crops such as maize, sorghum millet and rice. In addition, onion cultivation benefited from strong fertilizer and water inputs for watering. The specialization of the observed flora could be translated in this context of a technical route by the rotation of crops that did not cover the soil, by the high frequency, dominance and abundance of Portulaca oleracea and Cyperus rotundus, which were difficult species. to be controlled after several cultural successions (Bello et al., 2013, Bello et al., 2018, Bello et al., 2019a, 2019b). The variation in the floristic composition in terms of richness according to the seasons, highlighted by the present study, confirmed the findings of Bonte (2010) who had maintained that "the floras are not the same according to the season, that some The crops are cleansed because of the cultivation techniques used and others are quickly established and cover the soil well and are excellent competitors for weeds. " Cultural practices described in onion growing systems in the study area (Bello 2012, Bello et al., 2012a, Bello et al., 2012b, Bello et al., 2018, Bello et al., 2019a 2019b) and the results of this study explain the multi-year dynamics of the flora through its specialization towards a targeted flora, composed of a few dominant species that are difficult to control (Bello, 2013, Bello et al., 2018, Bello et al. al., 2019a; 2019b). It is obviously Portulaca quadrifida and Cyperus rotundus. This finding confirms the observations that "after the cultivation of a plot, appear in a few years, grasslands almost mono-specific against which farmers no longer have any means of struggle in the

classical routes "(Anonymous, 2002). It also corroborates the results of research that showed that "vegetable crops tend to select a more targeted flora, suitable for regular tillage, short rotations and high fertilizer inputs (Anonymous, 2004).

\section{Influence of continuous cultivation on fallowing and abandonment of plots}

Fallow indicator species include Portulaca quadrifida and Cyperus rotundus on sandy-clay soil and sandy-loam soils. To a lesser extent, Boerhavia diffusa, Cassia tora and Sida acuta have the same importance on sandy-clay soil. Portulaca quadrifida, Portulaca oleracea and Cyperus rotundus were cited as the most common, most abundant and most dominant species of onions, especially in the middle of the crop cycle (Bello, 2013, Bello et al., 2018, Bello et al. 2019a, 2019b). 
Decrease in yield with successive crops is related to decreased soil fertility in relation to decreased plant diversity, abundance, persistence, and increased dominance of weed species (Bello et al. 2013). against which manual weeding becomes manifestly ineffective. This situation characterized the strong competition of weeds for water, light, nutrients and space resources and justified the abandonment or setting aside of plots by the producers. Vernier et al. $(1995,1997)$ mentioned this effect of grass cover in Côte d'Ivoire where the invasion of plots of rainfed rice by Chromolaena odorata in a traditional system of shifting cultivation on slash-and-burn, and sometimes in association with maize, forced farmers to leave their land even before soil fertility problems appeared. The decline in yield from $32.5 \mathrm{t} /$ ha to $17.5 \mathrm{t} / \mathrm{ha}$, representing $46 \%$ yield losses after nine years of continuous cultivation, for both types of soil at the rate of a decline in fertility . This result was similar to that presented by Rodenburg et al. (2011) in Benin with rice farmers abandoning heavily infested Rhamphicarpa fistulosa traps due to yield losses that may exceed $60 \%$. According to Mangara et al. (2008), pineapple planters abandoned their land due to the inability to control excessive weed control.

The specialization of the flora observed over time in relation to the decline in yield suggests that time factors influenced the competition. Indeed, it is possible to say that the degree of infestation of crops by weeds increases with the duration of continuous cultivation, and consequently leads to a reduction in yield over time. This finding is consistent with the opinion of Marnotte (1995) who stated that "after several years of cultivation, weeds tend to dominate the plots where they are established". The comparison of the results of these authors with those of the present study makes it possible to deduce, like Akobundu and Poku (1987), that "the longer the weeds stay, the more they are competitors and their control is more difficult" . Akobundu (1987) stated that "it is the weeds that determine the size of the areas cultivated in production areas still characterized by ancient farming practices". The earlier fallowing of plots in the presence of Cyperus rotundus than Portulaca quadrifida is explained by the rapid reproduction of this species from its various propagules consisting of rhizomes, seeds and tubers, compared to Portulaca quadrifida, the reproduction of which is only based on stolons and seeds. Portulaca quadrifida and Cyperus rotundus have a generalized representation in the study area, with a preference for sandy-clayey soils (Bello et al., 2018), being degraded, moderately fertile and poor P. oleracea is cosmopolitan with a preference for very fertile soils (Bello et al., 2018) These observations corroborate those of Dunan et al. (1996) who reported that in addition to the duration of competition, onion density and weed load explain $75 \%$ of the variation in crop yield that is more sensitive to competition time than weed load.These comments and the results of Bello et al. (2018) present the agroecological context of grass onion in North-East Benin where onion growers report about $20 \%$ yield losses and fallow about $5 \%$ of the invaded plots after 3 to 5 years of continuous cultivation (Bello, 2004; 1lo, 2012).

The results of this study showed that the invaded plots of Portulaca quadrifida were abandoned earlier, from the first to the 8th year of continuous cultivation on sandy-clay soil, and from the 5 th to the 12 th year on sandy soils. silty. In the presence of Cyperus rotundus, this period is 4 to 10 years on sandy-clay soil and 5 to 12 years on sandy-loam soil. These two species are cosmopolitan with a strong strong ecological preference for sandy-clay soils in the study area at a variable frequency of $69 \%$ to $71 \%$ (Bello et al., 2018). 
The yield of onion bulbs is higher in sandy-clay soils than in sandy-loam soils and in close relationship for both soil types with soil fertility level. The long-term dominance of these species that results in fallowing or abandonment of plots may be related to a better expression of their mechanisms of survival, persistence and resistance to manual weeding in crop agro-ecosystems. onion.

In addition to the ecological preference of weeds, the initial fertility of cultivated soils and, more specifically, the conditions of chemical fertility that characterize sandy-clay soils, the intensive use of mineral fertilizers and the humidity associated with the regular watering characteristic of onion cultivation in this study area (Bello, 2012; Bello et al., 2018) explain in our opinion the trend of yields obtained.

\section{Influence of site conditions on onion bulb yield}

The results presented indicated that all the site condition variables studied had a significant influence on the level of onion bulb yield.

The positive correlation between soil texture and onion bulb yield indicated that yield was higher in sandy loam soil than in sandy loam soil, particularly in very fertile soil $(\mathrm{p}=0.000)$. On the other hand, the yield decreases with the continuous culture time $\left(\mathrm{p}<0.001, \mathrm{R}^{2}=91.9 \%\right)$ a regression of the yield is observed with the continuous culture time $(\mathrm{p}<0.001)$.

This is mainly due to the degradation of soil fertility related to nutrient exports and the reduction of organic matter. The main cause would lie in the low or no integrated management practice of soil fertility and grass cover, such as rotational rotation, recycling of crop residues, adequate mineral fertilization, non-burned, etc.

On plots with medium fertility, grass cover positively influences yield, probably because of the nature of the species present. Commelina benghalensis, Cyperus rotundus and Portulaca quadrifida were common to medium-fertile sandy-loam and sandy-clay soils. On moderately fertile plots, Boerhavia diffusa, Commelina diffusa, Cyperus tuberosus, Panicum subalbidum, Setaria pallidus fusca and Sida acuta were also present and distributed differently according to soil texture.

The positive influence of grass cover in plots despite the presence of Commelina benghalensis, Cyperus rotundus and Portulaca quadrifida can be explained by the average plot fertility level in relation to low levels of cover and density at certain periods of time. the growing season that needs to be determined later. In fact, an improvement in the level of soil fertility leads to a better yield of onion bulbs ( $p<0.001)$, particularly in sandy-clay soil $(\mathrm{p}<0.001)$, where the texture has a strong interaction influence with the level of soil. high fertility $(\mathrm{p}<0.001)$.

This analysis has shown that continuous crop time, soil texture, soil fertility level, and the presence of localized species on medium-fertility soils have a significant influence on yield.

The presence of localized soil species with high and low fertility levels, generalized guide species, and the presence of drop indicator species does not significantly influence yield. 


\section{Consideration of site factors and integrated management of grass cover}

Apart from rotation and other cultural practices (Leroy, 2011), the competitiveness of the crop, the interruption of the weed cycle mechanically or biologically, changes in sowing and fertilization dates, Use of previous cropping and tillage before sowing were proposed by Valantin-Morison et al. (2008). According to this author, the adoption of several control methods that can be used separately or in combination (Valantin-Morison et al., 2008), imposes a choice of tools and number of weedings that take into account the type of soil. , climatic conditions, species present, nature, stage of development and density of the crop and species of weeds present.

The results of this study have highlighted, like those of Valantin-Morison et al. (2008) that grass cover remains a problematic health issue for onion cultivation. On this basis, the management and sustainability of the technical itineraries requires a multi-year management of the crop succession.

\section{CONCLUSION}

This study showed that species are variously represented on soil types according to the duration of continuous cultivation, texture and soil fertility level. Thirteen species have a generalized representation in the agro-ecosystem, ten are subservient to moderately fertile soils, eight on fertile soils and seven on poor soils. Boerhavia diffusa, Cassia tora, Commelina diffusa, Cyperus rotundus, Panicum subalbidum, Portulaca quadrifida and Sida acuta are the most represented, associated with Portulaca quadriifida and Cyperus rotundus which appear at the end of the short rotation cycle and show a specialization of long-term flora.

Fallowing of sandy-clay soils is more delayed in the presence of Cyperus rotundus than of Portulaca quadrifida. The appearance of both species occurs after a long period of continuous cultivation on sandy-loam soil of about fifteen years.

The duration of continuous cultivation, the soil texture and soil fertility level and the presence of localized species on soil of average fertility, but also and especially the degree of grass and the number of dominant species have a significant influence on the yield of onion bulbs, which decreases significantly with the extension of the continuous cultivation time, by about $50 \%$ after nine (9) successive cropping seasons. Average and low yield levels are attributed to soil texture, and high and low yield levels are attributed to soil fertility level. Indeed, the degradation of soil fertility related to nutrient exports and the reduction of organic matter in a context of lack of integrated management practices of soil fertility and grass cover these findings.

These results demonstrate the complexity of the biological interactions that occur between onion and weeds and the need to consider several factors for effective and sustainable control of weed. These include soil fertility through its sustainable management, the degree of grass cover, the presence of species that have a localized soil distribution of average fertility level and the appearance of dominant species within the flora with the duration of continuous cultivation notably Commelina benghalensis, Commelina diffusa, Cyperus tuberosus and especially Cyperus rotundus and Portulaca quadrifida. 
In addition to flora monitoring, crop rotation and fallowing, even for short periods of time, and other practices such as manual weed control or combined with herbicide application can help to overcome the competition. the harmful flora of the onion.

\section{REFERENCES}

Akobundu I. O and Agyakwa C. W. 1989. Guide to weeds of West Africa. IITA, Ibadan, Nigeria; 522 p.

Akobundu I. O. 1987. Weed Science in the Tropics. Principles and practices. Wiley J. and Sons Ltd. (eds), Chichester, 522 p. ISBN 0471915440.

Akobundu I. O. and Poku J. A. 1987. Weed control in soybean in the tropics. in:

Singh S.R., Rachie K.O., and K.Edashiell (Eds) Soybean for the tropics: research,

production and use. John Wiley and Sons Ltd, Chishester. Pp 69-77.

Anonymous. 2002. Memento de l'agrronome, 2002 editions. CTA, CIRAD and GRET (eds), CD-ROM version.

Anonymous. 2004. Endemism and biological invasions of terrestrial ecosystems in insular areas: Crop weeds and invasive plants. CIRAD, 2004 (ed.). Annual report CIRAD-Réunion. pp. 76-77.

Bello S. 2004. Report on the completion of action research contracts for the Onion program for the 2001-2004 seasons. INRAB-CRAN / PADSE, 106 p.

Bello S. 2012. Diagnostic analysis of the production and marketing of onion (Allium cepa L.) from 1995 to 2009 in North-East Benin. Bulletin of Agronomic Research of Benin (BRAB) $\mathrm{N}^{\circ}$ 71 of June 2012, published on January 15, 2013.

Bello S. 2013. Participatory development of a technical itinerary for the integrated management of onion weeds (Allium cepa L.) in northeastern Benin. Single doctoral thesis, University of Abomey-Calavi, Faculty of Agricultural Sciences, Abomey-Calavi (Benin), 352 p.

Bello S., Adam A., Amadji G. L. 2018. Agro-ecological and sociocultural significance and weed infestation of onion weeds in northeastern Benin. Presented at the celebration of World Soil Day on the theme: Soil Pollution. Organized by the Laboratory of Soil Microbiology and Soil Microbial Ecology (LMSEMS) of the Faculty of Agricultural Sciences of the University of Abomey-Calavi (FSA / UAC), December 2018, 20 p.

Bello S., Ahanchede A., Amadji G., Gbèhounou G. and Aho N. 2012b. Effects of mineral fertilization on grassland and onion production (Allium cepa L.) in northeastern Benin. Int. J. Biol. Chem. Sci. ", December 2012, 6 (6): 4058-4070. ISSN 1991-8631. DOI: http://dx.doi.org/10.4314/ijbcs.v6i6.16. Website: http://indexmedicus.afro.who.int.

Bello S., Ahanchede A., Amadji G., Gbèhounou G. and Aho N. 2013a. Seasonal evolution of weed flora and harmful effects of onion plots (Allium cepa L.) in northeastern Benin. Submitted 
in simplified version for communication and publication in the proceedings of the 22nd Conference of COLUMA organized by the French Association of Plant Protection (AFPP): International Days on the fight against weeds, held in Dijon, 10, 11 and December 12, 2013. Ch 7

Bello S., Ahanchede A., Gbèhounou G., Amadji G. 2019a. Determination of periods of early, critical and late competition of onion weeds (Allium cepa L.) in northeastern Benin. Submitted and accepted for publication by International Journal of Biological and Chemical Sciences (IJBCS) under the reference No. 8122-IJBCS dated 23 January 2018 at 12:31.

Bello S., Ahanchede A., Gbèhounou G., Amadji G. and Aho N. 2013b. Floristic diversity, ethnobotany and local taxonomy of onion weeds (Allium cepa L.) in northeastern Benin. TROPICULTURA, 2013, 31 (2): 53-63.

Bello S., Amadji G., Gbèhounou G., Aho N. and Ahanchédé A. 2012b. influence of transplanting density on grassland and onion production (Allium cepa L.) in northeastern Benin. Journal of Animal \& Plant Science, 2012, 15 (1): 2074-2082. Publication date 31/8/2012, ISSN 2071-7024. Website: http://www.m.elewa.org/JAPS

Bello S., Amadji L. G. and Adam. A. 2019b. Technical efficiency and economic profitability of cultural and chemical control methods of onion-grown weeds (Allium cepa L.) in northeastern Benin. Submitted and accepted by the magazine Base, $22 \mathrm{p}$.

S. Bello, Assogba-Komlan F. V. and Baco M. N. 2004. Practical guide to the production of onion bulbs in the department of Alibori. INRAB / AFD / PADSE (eds), 54 p. ISBN No. 9991951-64-4.

Kindness J. B. 2010. Crop rotation in organic cereal systems: can we combine economic, agronomic and environmental performance? First multi-criteria analysis approach. Higher Institute of Agriculture (ISA Group) and Institute of Plants (ARVALIS) (eds.), 67 p.

CARD Borgou-Alibori. 1991. Annual report for the 1990-1991 crop year. MDR, 82 p.

Caussanel J. P. 1989. Weed nuisance thresholds and weeds in an annual cropping system: bispecific competition situation. Agronomy, 9: pp. 219-240.

CeCPA (Communal Center for Agricultural Promotion) Karimama. 2006. Annual Activity Report, 2006-2007 Campaign. Karimama, Benin. 21 p.

CeCPA Karimama. 2008. Annual Activity Report, 2007-2008 Campaign. Karimama, Benin. 25 p.

CeCPA Malanville. 2006. Proposed Malanville CeCPA program budget for 2007, Malanville, Benin, $14 \mathrm{p}$.

Chicoučne D. 1999. Evaluation of the stand of weeds in vegetation in a plot. Overview of the methods that can be used Phytoma, 522: pp. 22-41. 
Cousinie P., Djagni K. and Faure G. 1989. Togolese agriculture in the cotton zone: from analysis to recommendations. Summary report of the agricultural campaigns from 1985 to 1989. CIRADIRCT, Lomé, Togo, 25 p.

Douti P.Y. and Djagni K. 1995. Weed cotton plant: what is the competition period? Agriculture and Development, No. 7, September 1995: pp. 31-36.

Dunan C.M., Westra P., Moore F. and Chapman P. 1996. Modeling the effect of weed competition, weed density and weed competitiveness on seeded, irrigated onion. Weed research, 36 (3): pp. 259-269.

Faure L., Jallas E., Douti P. Y., Faure G. and Djagni K. 1988. Annual report 1987. Herbicide experiment in real environment. Research and development project. CIRAD-IRCT, agronomy and agro-economics sections, Anié-Mono station, Togo, 20 p.

ITAB. 2005. Controlling Weeds in Field Crops: A Technical Guide. Technical Institute of Organic Agriculture, 119 p.

Bourgeois T. 1993. Weeds in cotton rotation in North Cameroon (Africa). Doctoral Thesis, USTL, Montpellier II, France, 249 p.

Leroy A. 2011. Study of the evolution of grassland plots from 2002 to 2011. ISA-Lille, GRAB Upper Normandy, Faculty of Science and Technology Free, Ministry of Agriculture and Fisheries of the French Republic, Municipality of the Upper Normandy Region, the Plots Network on the Adventures in Large Organic Cultures of Haute-Normandie, the Groupement des Agriculteurs Biologiques of Haute-Normandie and ITAB (eds.). Master's thesis, September 2011, 79 p.

APRM. 2002. Final report: geo-referenced database on agricultural land use in Benin. MAEP, DFRN, CENATEL, FAO (eds.). November 2002, 20 p.

Mangara A., N'da Adopo AA, Boraud MKN, Kobenan K., Lejoly J. and Traore D. 2008. Inventory of the adventitious flora in pineapple culture (Ananas comosus (L.) Merr.) In the locality of Bonoua in low Ivory Coast. African Agronomy, 20 (1): pp. 23-35.

Marnotte P. 1995. Use of herbicides: constraints and prospects. Agriculture and Development, No. 7 - September 1995, pp. 12-21.

Mesbah A., Miller S.D., Fornstrom K.J. and Legg D.E. 1994. Sugar beet-weed interactions. Agricultural Experiment Station. Department of Plant, Soil and Insect Sciences, College of Agriculture. University of Uwyoming. B-998, August 1994. 4 p.

Nieto J.H., Brondo M.A. and Gonzalez J.T. 1968. Critical periods of crop growth cycle for competition from weeds. Pans, 14 (2): pp. 159-166.

PADSE. 2001a. Geographical zoning and typology of farm operations: Summary of the results of support missions to the village surveys component. Parakou, Benin. 63 p. 
PADSE. 2001b. Development of a typology of farm operations in the Niger and South Zou Valley: Proposals for the use of the typology. Parakou, Benin. 44 p.

Rodenburg J., Zossou-Kouderin N., Gbèhounou G., Ahanchédé A., Touré A., Kyalo G. and Kiepe P. 2011. Ramphicarpa fistulosa, parasitic weed threatening rain-fed lowland rice production in sub-Saharan Africa- A case study from Benin. Crop Protection, 30 (10): pp. 13061314. ISSN: 02612194. DOI: 10.1016 / j.cropro.2011.06.007. Available from linkinghub.elsevier.com. Accessed April 10, 2009 at 4:10 pm

Website: http://www.theplantlist.org/: Updated database of plant systematics.

Tonato S.H., Douti P.Y., Cousinie P. and Djagni K. 1990. Annual Report 1989. Herbicide experimentation in a real environment. Research and development project. CIRAD-IRCT, agronomy and agroeconomy sections, Anié-Mono station, Togo, $21 \mathrm{p}$.

Tonato S.H., Jallas E., Douti P. Y., Faure G., Djagni K. and Trekou K. 1989. Annual Report 1988. Herbicide experimentation in the field. Research and development project. CIRAD-IRCT, agronomy and agroeconomy sections, Anié-Mono station, Togo, 21 p.

Valantin-Morison M., Guichard L. and Jeuffroy M. H. 2008. How to control the adventitious flora of arable crops through the elements of the technical itinerary? Agronomic Innovations, 3: pp. 27-41.

Vernier P., Gbaka T.H., Tehia K.E., Marnotte P. 1995. The control of grass cover of cereals in ivory coast. Agriculture and Development, No. 5, March 1995: pp. 51-56.

Vernier P., Gbakak H., Tehia E., Marnotte P. 1997. Weed control in cereal cropfields in Ivory Coast. Agriculture and Development, Spec. No., pp. 42-46, 6 ref., 1 card, 2 tabl., 4 graph. 